\title{
The Role of Insurance to Protect the Right of Passengers in Air Transport in Case of Damage to Healih, Injury or DISPOSAL OF PASSENGERS
}

\section{Abstract:}

The paper deals with how carriers in air transportation sector are to deal with their liability in systematic manner, with an emphasis on passengers rights. National, international, and European Union regulations are scrutinized concerning the obligations and responsibilities of the carriers arising from a contract for carrying of persons (passengers], in the adverse event of damage to health, injury, and/or death. Furthermore, what options are available to the passengers in seeking monetary compensation regarding both property, and non-property damages. The stress is on insurance against liability which may arise from referenced contract, and also the benefits of institute of compulsory as well as voluntary insurance policy.
This particular topic is very interesting, due to socalled travel law can be specified as a sub-branch of transportation, and/or respectively transport. Therefore, the sources of legal rights of so-called passenger's rights are based on threedimensional level, in terms of applying and comparing the legal sources on national, international, and European level.

\section{Keywords:}

Carrier liability; damage due to passenger injury or death; montreal convention; Regulation 889/2002

\section{Author's data:}

'lecturer, Prison in Požega, Osječka 151 A, Požega, visnja.tomicdalic@uzs.pravosudje.hr 2 Polytechnic in Požega, Vukovarska 17, Požega, dursic@vup.hr

International Journal - VALLIS AUREA • Volume 5 • Number 1 • Croatia, June 2019 


\section{Introduction}

The insurance institute acts as a foundation as protection for business in order to conduct commerce. Purely from economic standpoint, as the businesses' profits increases, they have an even higher interest and a need to insure their assets from potential harmful consequences. Recent technological advances have aided air carriers to increase their capital accumulation, and at the same time, earned capital is further-more invested in financial vehicles with higher risks. It is clearly imperative for companies to do everything in their power in order to avoid potential accidents. To maximize protection, in conjunction to purchasing insurance policy, they engage technological security measures as preventive measure. In a case of un-avoidable incident, the liability for damages and it compensation would fall on the policy underwriter.

In parallel with the development of transport branches, and thus the transport of passengers through all branches of transport, that is, transport of passengers by road, rail, inland waterways, sea waterways and relatively new air transport, there has been an increasing need for passenger insurance. Transportation of passengers at the very beginnings of the transport sector took place together with the transport of things. The first appeared on road transport, then maritime and river, and rail transport, which is special due to the infrastructure itself, as it depends on the construction of railway lines. Air transport is the latest developed. We assume that the wide range of traffic spectrum through various transport branches has led to the growing need for the development of a special insurance institution for passengers. The interest of an individual to look for some form of security and protection results in an increasing demand in the economic market, and therefore an ever-more global system of insurance. Passenger insurance can be studied on both sides, as a form of passenger protection, but also as a carrier protection. In what sense? It is important to say that the occurrence of passenger insurance provides certain security in case of damage occurring to the injured party through the insurance institute itself, and by the insurer, who, under the insurance contract and the occurrence of the damage, is obliged to pay a certain fee on the basis of a direct request injured parties. Thus, the injured party is enabled to send a direct claim for compensation to the insurer, which in any case is a much more acceptable and more solvent debtor than the carrier itself. on the other hand, the carrier, whose responsibility for the resulting damage arises from the contractual relationship under the contract of carriage, by paving the insurance premium to the insurer leaves the damage to the injured party directly from the insurer. This is also protected by the carrier from damages, but in what form and in which way we will explain it in more detail. It is important to note that this is not excluded from liability of the carrier, nor is he exempted from liability, but by this method he is provided with a system of protection against excessive damages that could arise during his business and lead him to complete ruin.

In order to prevent risky business of transport activity through all branches of transport, a state intervention was necessary in terms of the introduction of a compulsory insurance institute. The compulsory regulations are precisely certain forms of compulsory insurance, as well as the obligation to make compulsory insurance and the 
risks covered by the insurance. An example of such a regulation is the Law on Compulsory Motor Insurance [1]

\section{Methodology For Inspection In Air Transport}

The insurance of passengers in air transport or passenger rights is based on a comparative or comparative methodology, ie a three-dimensional comparison of legal sources at national, international and European level. By researching and studying thoroughly, we will finalize considerations with a focus on defining the role of the insurance institute in the protection of passenger rights. This topic is very interesting since the so-called. the passenger right can be specified as a subordinate transport or transport right. Particularly the matter of passenger law is regulated by special national, international and EU regulations. Since we have become a full member of the EU, European regulations are also mandatory in our system, and comparing our national regulations with Europe is particularly interesting in this area of passenger law. Therefore, the processing of legal sources of so-called " passenger rights in this paper is based on a threedimensional level in terms of application and comparison of legal sources at national, international and European level. $\$ 0$, by means of a comparative method of presenting the legal arrangement of passenger rights, we can come to specific conclusions regarding the role of insurance in the protection of passenger rights at the national, international and EU level.
Results and Disputes on the Protection of the Right of Passengers in Air Transport

\section{Producing Right of Travel in Accordance With} Croatian National Law

According to the Convention on the Equalization of Certain Rules in International Air Iransport (hereinafter Montreal Convention], which entered into force on 4 November 2003 [2] and Croatian regulations provide for a two-stage system of liability for damage caused by the death and bodily injury of passengers pursuant to Articles 15 to 22 . Law on obligatory and Really Legal Relations in Air Iransport [3] Prior to these provisions, the Decision on Monetary Measures Limiting the Responsibility of National Carrier Air Navigation [4], which was later abolished, was applicable because it was not aligned with the Warsaw Convention and its Protocols.

This means that an air carrier is held accountable on the basis of objective liability in the event of damage of up to 100,000 special drawing rights [SDRS] per passenger without the possibility of exclusion or limitation of liability. However, there is a situation where the carrier fully or partially releases the liability in the event that he or she proves that the damage was caused or its creation has contributed to the negligence or other unlawful act or omission of the person seeking remuneration or to the person from whom he exercises his rights to the extent that such negligence, unlawful act or omission caused or contributed to its creation. Likewise, the carrier shall be wholly or partly exempt from liability where compensation for damage due to death or bodily injury to a passenger requires a person other than the passenger himself, to the 
extent that the carrier proves that the damage was caused or that its occurrence was contributed by negligence or other unlawful act or failure of that passenger [5]. Thus, the carrier has the ability to diminish its responsibility proportionately as stated, of course, under the provisions of the Montreal Convention. The second level of liability of a carrier relates to claims claims exceeding the amount of 100,000 special drawing rights (SDRS) per passenger where an air carrier is liable on the basis of guilty grounds, according to the criterion of subjective liability where the airline's guilt is assumed. In these cases the carrier agrees unlimitedly. However, here too it is possible to freely or partially release a carrier if it proves that:

a. the damage did not arise due to negligence, or any other harmful effect or omission of the carrier or its officers or agents, or

b. That the damage was caused by negligence or other adverse effects or omissions by a third party [5]

This two-way accountability model has been in use since 2009. However, it is important to note that our largest national air carrier, Croatia Airlines, has applied this system of liability of the air carrier on the basis of objective liability criteria up to 100,000 special drawing rights from 1995 onwards based on the guilty plea. Namely, Croatia Airlines is a member of the International Air Transport Association (IATA), which applied this mode of responsibility irrespective of national regulations. Based on our General Terms, our domestic air carrier has already taken on contemporary cargo liability models and equalized the rights of passengers in domestic and international transport, despite a completely different legal norm.
Prohibition of Travel Rules Under International Law

Air transport is a relatively new branch of transport that has a multitude of regulations, conventions and treaties. Consequently, we will list certain conventions and their key provisions in order to get a clearer picture of the importance of today's regulations in force. First of all, we will start from the Warsaw system and make the following conventions and its protocols:

-The Warsaw Convention-Convention on the Equalization of Certain Rules on International Carriage by Air of 1929 . This convention provided for a limited subjective liability of the carrier on the basis of guilty plea for the death or bodily injury of a passenger to a sum of 125000 gold francs per passenger for hand- baggage of 5000 gold francs per passenger, and for gifted baggage of $250 \mathrm{gold}$ francs per kg

- The Hague Protocol - Protocol amending the Convention on the Equalization of Certain Rules on International Carriage by Air, 1929, adopted in 1955. introduces a higher limit of liability of the carrier to the amount of 250,000 gold francs, simplifying the provisions on transport documents. -The Warsaw Convention on the Amendment of the Warsaw Convention, adopted in 1961, introduces the equalization of the responsibility of the actual and contractual carrier

-Guatemals Protocol on Amendments to the Convention on the Equalization of Certain Rules of International Air Transport, 1929, adopted in 1971. It introduces a system of objective liability of the carrier and raises the limit of liability for death or injury of passengers to the amount of $1.500 .000 \mathrm{gold}$ medals 
-Montreals Protocols for Amendments to the Warsaw Convention adopted in 1975. It represents the previous three protocols (1 Warsaw Convention, 2.Hasic Protocols 3.Guatemals Protocol, and Protocol No. 4. It introduces objective objectives of carrier and freight transport.

We will further mention the Montreal Agreement of 1966 that we can not take a formal agreement or revision of the Warsaw Convention, but a private agreement between the airline carriers of IATA (International Air Transport Association) carriers involved in US / and who have given great criticism to the Warsaw Convention because of the overly restrictive responsibilities that have led to the objective liability of the carrier, the gamble of responsibility raised to $\$ 75,000$. Thus, in this series, a significant IATA-Intergovernmental Agreement has in fact three separate agreements: the IATA Intergovernmental Agreement on Passenger Responsibility, the Agreement on Measures Received by the IATA Intergovernmental Agreement, by the Agreement. In this Agreement, the 1995 IATA member states all limitations of air carrier liability imposed by the Warsaw system and introduces a system of objective liability up to the limit of 100,000 SDR, and over that limit corresponds to the full amount of the claim based on the guilty plea. This has expanded and territorial application of the Agreement to all cargo contracts by the signatories of this Agreement, not only on the territory of, or in the United States, as regulated by the Montreal Agreement of 1966.[6]. The Warsaw system[6] has been in force for many years, but the tendency of unification and equalization of international rules has led to the following convention:

- Montreal Convention of 1999. [6] which introduces a two-stage liability liability system for the death and bodily injury of passengers, which means the carrier's objective liability of up to 100,000 SDR per passenger and over this amount corresponds to the assumed guilt in fact unlimited according to the 1995 IATA Agreement and EU Regulation 2027/97.

In any case, the Montreal Convention was a model for our legislation, as it has been accepted and ratified by us, and our regulations are fully harmonized. We have especially seen this by the ZOSOZP, which takes over the entire agreement system on passenger and luggage transportation and the responsibilities in this area from this Convention[5].

of course, it is necessary to mention the following conventions and protocols that have contributed to the development of international aviation, particularly in the field of passenger and luggage transport:

- Convention on the Allocation of Certain Rules of Damage Caused by Third-Party Airplanes on Third Country Land Issued in Rome, 1933, which for the first time prescribes the objective liability of the carrier for damages caused by the aircraft to persons on the ground, but no new convention has been entered into force:

- The 1952 Rome Convention, which entered into force on 4 February 1958 . is based on the objective liability of the owner or aircraft user for damages caused to third parties on the ground caused by the aircraft - The Montreal Protocol of 1978, which entered into force on 25 July 2002. introduces some amendments to the 1952 Rome Convention, but R Croatia has not acceded to this convention or its protocols

Protect the Rule of Travel in Accordance With EU Provisions 
Accession to the EU preceded the year and year of preparation and alignment of our legislation with EU regulations in order to be able to function in that multi-state system, which nevertheless allows for the preservation of its sovereignty and autonomy, yet it demands association for better economic activity. officially, the process of aligning our Iegislation with the European Union started with the signing of the Stabilization and Association Agreement with the EU on 18 October 2001. This agreement has obliged croatia to adapt its Iegislation regarding administrative, technical and other regulations to EU Iegislation that is at a particular moment in air and land transport. So we can immediately mention art. 184.d. 20SOZP who says that this law is in line with European regulations[7]. In the chronological order of the guidelines and ordinances we will clarify each one individually with a short summary:

1. Council Directive 90/314 / EEC of 13 June 1990 on package travel, package holidays and package travel as set out below Directive 90/314 / EEC [8] This guideline provides the right of passengers to obtain accurate travel information and guarantees certain rights if the travel organizer does not meet the agreement.

2. Council Regulation (EEC) No 295/91 of 4 February 1991 on the establishment of common rules for the denial-of-service compensation scheme for scheduled air services (hereinafter: Regulation 295/91] [9]

This decree referred to the denial of boarding because of the overbooking overcrowded. The scope of this Regulation covered only flights departing from the airport in the Member State. The provisions concerned only the denial of embarkation, therefore it was necessary to extend these provisions made by Regulation 261/2004.

3.Council Regulation (EC) No. 2027/97 of 9 November 1997 on Airborne Accidents Responsibility Regulation 2027/97 [10]

This decree regulates the liability of an air carrier in the event of an accident, and has been made due to the increasing need for passenger protection due to the excessive limits of liability and the lengthy court proceedings and the need to harmonize international and domestic rules. It introduces a two-tier liability system where the carrier responds on the basis of objective liability limited to the amount of 100,000 SDR, and over this amount based on the guilty plea. The carrier may be absolved of liability in whole or in part if it proves that the passenger caused or contributed to the damage. The news item is that there is an obligation of an air carrier to make compulsory liability insurance in the amount of 100,000 SOR per passenger. Prepayment is also provided for a minimum of 15,000 SDR in the event of a person's death. These separate newspapers are in fact the provisions that air carriers must specify in their General Business Conditions.

4. Council Regulation (EC) 889/2002 of the European Parliament and of the Council of 13 May 2002 amending Council Regulation (EC) No 2027/97 on air carrier liability in the event of accidents - to Regulation 889/2002 [11]

It is primarily this decree that the provisions of the Montreal Convention apply to the carriage of passengers and luggage. Also, this decree introduces some newspapers, so raising the amount of advance payment at 16,000 SDRs for death. Thus, certain provisions relate to the rights of all passengers to a summary of all the relevant 
regulations relating to liability for passengers and their luggage, and carriers are obliged to provide written notice of the liability liability of the carrier in the event of death or injury to the passenger for that flight.

5. Council Regulation 261/2004 of the European Parliament and of the Council of 11 February 2004 on the establishment of common rules on compensation and assistance to passengers in the event of denied boarding and cancellation or long delay of flights and repealing Regulation (EEC) 295/91 [12]

This Decree replaces the 1991 Decree, which refers only to denied boarding and extends its provisions on flight cancellation and flight delays. Our ZOSOZP is fully aligned with this decree, so I'm referring to the section that talks about it. Also, the general condition of our air carrier includes a notice to passengers on Regulation 261/2004 of the European Union which regulates passengers' rights due to deferred embarkation, flight cancellation or longer delays in air transport.

\section{Insurance of Passengers in Air Transport}

\section{Obligatory Insurance in Air Transport}

A. OBLIGED INSURANCE UNDER Law on Compulsory Motor Insurance

We differentiate between two types of compulsory insurance in air transport:

a. Insurance of air carriers or airline operators of liability for damage caused to third parties and passengers

b. Insurance of Passengers in Public Transport Due to Accidents
Therefore, we will individually handle each type of compulsory insurance.

a. Insurance of air carriers or airline operators of liability for damage caused to third parties and passengers

Obligatory insurance in air transport is a type of contractual insurance because it is created by the conclusion of an insurance contract. According to the Law on Compulsory Motor Insurance, insurance is provided for the air carrier, ie air carrier, of liability for damage caused to third parties and passengers as compulsory insurance in air transport. Obligations to conclude this type of insurance are all air carriers and aircraft operators registered pursuant to Regulation 785/2004[13] if they are in the territory of the Republic of Croatia or in its airspace. In this insurance, as well as the insurance contractor, the aircraft operator is due to his specific responsibility for later. The definition is that "the operator of the aircraft is a person or entity other than an air carrier and who constantly and actively decides on the use or operation of an aircraft; it is assumed that the aircraft operator is a natural or legal person on whom the aircraft is registered, unless that person proves that another person is an operator. "This means that the aircraft operator is either the aircraft owner or the actual aircraft operator who is responsible for certain situations. The aircraft operator is responsible for the damage caused to the earth due to the death or bodily injury of a third party and to the damage caused to the aircraft caused by the aircraft for the damage caused by the things that were fired or thrown out of the aircraft in flight. [3]The aircraft operator may be fully or partially release the liability if the damage was caused by the action of 
the injured party or the person who worked on the order and for the injured party in proportion to the contribution of the said persons in the event of damage. If a harmful action is caused by the operation of a third person, the operator of the aircraft corresponds to the solidarity of the burden of his guilt. According to the above mentioned situations, full or partial release of the aircraft operator's liability may result. Only to the full release of liability comes in the situation when the damage was caused by the cause outside the aircraft, whose actions could not be foreseen or avoided or eliminated. The responsibility for damage due to death or bodily injury amounts to 100,000 special drawing rights per killed, injured or injured.

This insurance covers the following damages:

- Damage to third parties due to death, bodily injury or disruption of health, destruction or damage to property during flight

- Damage due to death, bodily injury or disturbance of passengers' health during aircraft flight

- Damage to the loss of personal belongings of passengers in the aircraft cabin

- Damages due to loss or damage to cargo and delivered luggage

From the aforementioned damages we can see that this insurance covers damage to third parties, travelers and their luggage and their cargo. Third parties are considered to be any natural or legal person other than passengers and members of flight and crew during flight of aircraft. Passengers are persons who are transported with the consent of the air carrier or airline operator. Flight and cabin crew members are not considered passengers.

This insurance covers the basic transport risks we have mentioned in the previous branches of transport, as well as the additional transport risks we have not mentioned so far, since they have not been covered by compulsory insurance. These are the following risks:

- war operations

- terrorism

- kidnapping

- sabotage

- unlawful appropriation of aircraft

- public disturbances

Reasons for introducing additional risks in the compulsory insurance policy are increasingly frequent causes of harm to thirds or passengers, and especially terrorist attacks.

In any case, by the occurrence of a secured case, the injured party has the right to submit a direct claim for compensation to the insurer who, on the basis of the insurance policy, pays the amount of the insured amount provided for by law. The lowest insured amount amounts to third parties:

- 750,000 SDRS up to 700,000,000 SDRs for aircraft of $0-500,001 \mathrm{~kg}$

The lowest insured amount for a particular passenger is 250,000 SDR except for the carriage of passengers by an aircraft with an MTOM of 2,700 kg or less and which is not used for commercial purposes when the lowest insured amount is 100,000 SDRS. Also, the lowest secured baggage allowance of 1,000 SDRS and a charge per $\mathrm{kg} 17$ SDR is also specified.

These statutory provided sums can be increased, but the Government of the Republic of Croatia decides solely on this.

b. Insurance of Passengers in Public Transport Due to Accidents

Secured[14] 
This insurance provides exclusive protection to passengers since air carriers or aircraft operators carrying out the carriage of persons and things in public air transport are obliged to conclude the insurance policy. Travelers are considered to be persons on board an aircraft, in an air port or in the immediate vicinity of the means of transport prior to boarding or after boarding. Passengers are also considered to be persons entitled to free ride.

The lowest insured amount per one incident per passenger is:

- in case of death 40.000,00 HRK

- in case of permanent disability 80.000,00 HRK

The passenger has the right to submit a direct claim to the insurance company with which the air carrier has concluded the insurance contract, thereby enabling a faster and easier way of collecting the damage suffered.

B. OBLIGATORY INSURANCE BY LaW on Obligatory and Really Legal Relations in Air Transport

Compulsory insurance under Law on Obligatory and Really Legal Relations in Air Transport implies air transport insurance to which the provisions of the Maritime Code apply. Thus Art. Articles 743 to 747 of the CM provide for an obligation on an air carrier to ensure, by virtue of its liability for damage caused to third parties, to an appropriate height. An adequate amount means the amount of insurance that would be sufficient to settle the total compensation in an eventual damages for any person who would be entitled to compensation. The law does not specify the exact amount of insurance required but is left to the decision makers themselves with regard to the different aircraft capacities or the number of passengers that an aircraft can carry. Thus, the amount of 100000 SDR would multiply the number of passengers and get the limit to which the carrier would have to provide. of course this is only the lowest secured sum, but it can certainly be bigger.

\section{Insurance Under Montreal Convention and EU Provisions}

The compulsory insurance mentioned above under point a has been fully taken over by Regulation 785/2004. thus achieving consistency with European regulations. Given that at international level, the Montreal Convention provides for the compulsory insurance of the liability carrier provided for in this Convention without any detailed definition of the amount of the sum insured. In view of this, the provided sum includes the limit on the liability of the carrier, which is in fact 100000 SDR per passenger, as well as the provisions of Regulation 889/2002 (or Regulation 2027/97), which also provides for compulsory insurance of the carrier to legal limitation of the amount of liability for damages. However, this decree is in full compliance with the Montreal Convention, the EU accession, and in its provisions regulating the same area, it merely invokes the provisions of the Montreal Convention, while other rights are specifically identified and at the same time avoided the conflict of jurisdiction between these two sources of rights.

\section{Conclusion}

At national Ievel, all carriers are subject to the institute of compulsory insurance of passengers in public traffic due to the accident. This type of insurance is a standard form of insurance in favor of a third party where the carrier as the policyholder pays a premium in the event of an accident the 
insurer pays to the passenger an accrued amount of insurance. The insured case in this insurance is the occurrence of the injury or death of a passenger and on this basis the basis for the payment of the insured is created. The Law on obligatory Traffic Insurance, in addition to this compulsory insurance, also prescribes the compulsory liability insurance for damage caused to third parties and passengers. It is important to emphasize that this is a liability insurance in which the carrier is actually insured and paid the premium if an accident in which his responsibility was established and that he would not pay the compensation himself to the injured party, the injured party submits his claims to the insurer who pays the amounts to a statutory amount. This compulsory liability insurance provides legal protection for passengers in all branches of transport. In any case, the institute of compulsory insurance of passengers in all branches of transport, both on an international and EU level, the passenger is significantly protected and very likely that his damage will be fully recovered. The liability insurance institution for the damage caused to the passenger derives from the need to protect not only the injured passenger but also the carrier with respect to the contractual liability of the contract of carriage of persons. Namely, its responsibility is prescribed by law with the possibility of limited liability, which is fully harmonized at the national, international level and EU regulations (Pictures No.1]. The legal protection of the passenger is significantly strengthened by the insurance institute and gives the passenger the assurance that his damages will be settled. The compliance of these regulations provides for equality of all passengers and equal rights in all situations arising from the carriage of passengers.

\section{Pictures}

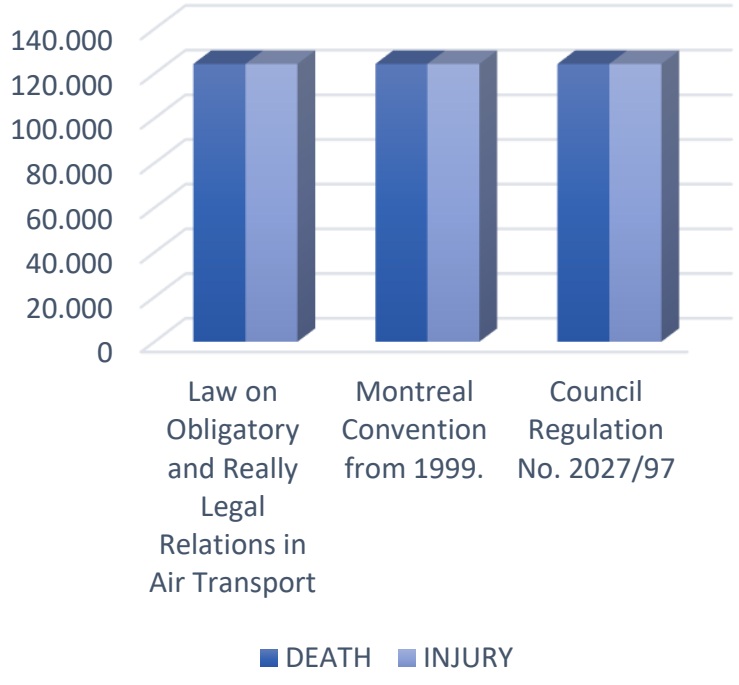

Picture 1. Representation of the limit values of liability of carriers in the air transport of passengers (values expressed in the currency: euro-0n 3. 4. 2019]. [15]

\section{References}

[1] Zakon o obveznom osiguranju u prometu, NN $76 / 13,152 / 14$.

[2] Međunarodni ugovori, NN 1/08.

[3] Zakon o obveznim i stvarnopravnim odnosima u zračnom prometu, NN 94/13.

[4] Odluka o novčanim iznosima do kojih se ograničava odgovornost prijevoznika u zračnoj plovidbi u nacionalnoj valuti, NN 47/93, 37/95.

[5] Konvencija za izjednačavanje nekih pravila u međunarodnom prijevozu zrakom (Montrealska konvencija], Zbornik Pravnog fakulteta u Zagrebu br.1(2004),str.203-224.

[6] Radionov, N.; Capeta T.; Marin J.; Bulum, B.; Kumpan, A.; Popović N.; Savić I. [2011). Europsko 
prometno pravo, Pravni fakultet Sveučilišta u Zagrebu, ISBN 978-953-270-054-1, Zagreb

[7] Kaštela, S.; Horvat, L. (2008). Prometno pravo, Školska knjiga, ISBN 978-953-0-30373-7, Zagreb

[8] Direktiva Vijeća 90/314/EEC od 13. lipnja 1990 paket putovanja, paket odmor i paket ture provizija: Council Directive 90/314/EEC of 13 June 1990 on package travel, package holidays and package tours Commision, 0J L 158,1990.

[9] Uredba Vijeća (EEZ) br 295/91 od 4. veljače 19910 utvrdivanju zajedničkih pravila za zanijekaointernat sustav kompenzacije u redovnom zračnom prometu Council Regulation (EEC) No 295/91 of 4 February 1991 establishing common rules for a denied-boarding compensation system in scheduled air transport, 0J L 36,1991.

[10] Uredba Vijeća (EZ) br 2027/97 od 9 . Iistopada 1997 o odgovornosti zračnih prijevoznika u slučaju nesreće Council Regulation (EC) No 2027/97 of 9 October 1997 on air carrier liability in the event of accidents, OJ L 285, 1997.

[11] Uredba (EZ) br 889/2002 Europskog parlamenta i Vijeća od 13. svibnja 2002 o izmjenama i dopunama Uredbe Vijeça (EZ) br 2027/97 o odgovornosti zračnog prijevoznika u slučaju nesreće Regulation (EC) No 889/2002 of the European Parliament and of the Council of 13 May 2002 amending Council Regulation (EC) No 2027/97 on air carrier liability in the event of accidents, 0J L 140, 2002.

[12] Uredba (EZ) br 261/2004 Europskog parlamenta i Vijeća od 11. veljače 2004 o utvrđivanju zajedničkih pravila o naknadi i pomoći putnicima u slučaju uskraćenog ukrcaja i otkazivanja ili dugog kašnjenja letova i ukida Uredba (EEZ) № 295/91 Regulation (EC) No 261/2004 of the European Parliament and of the Council of 11 February 2004 establishing common rules on compensation and assistance to passengers in the event of denied boarding and of cancellation or long delay of flights, and repealing Regulation (EEC) № 295/91, 0J L 46, 2004.

[13] Regulation (EC) No 785/2004 of the European Parliament and of the Council of 11 February 2004 establishing common rules on compensation and assistance to passengers in the event of denied boarding and of cancellation or long delay of flights, and repealing Regulation (EEC) № 295/91, 0J L 46, 2004.

[14] Curkovič, M.; Jakovina, D. \& dr. (2006). Novi propisi iz osiguranja-Zakon o osiguranju i Zakon 0 obveznim osiguranjima u prometu, Inženjerski biro, ISBN 953-6447-98-3, Zagreb

[15]www.hnb.hr/temeljne-funkcije/monetarnapolitika/tecajna-lista/tecajna-lista 